\title{
Combined analysis of trace elements and isotopic composition of particulate organic matter in suspended sediment to assess their origin and flux in a tropical disturbed watershed ${ }^{\text {is }}$
}

\author{
Alexandre Martins Fernandes ${ }^{a}$, Christophe Hissler ${ }^{\text {b }}$, Fabiano Tomazini da Conceição c, *, \\ Eder Paulo Spatti Junior ${ }^{c}$, Jefferson Mortatti ${ }^{\mathrm{d}}$ \\ a Faculdade de Engenharia de Bauru - Universidade Estadual Paulista “Julio de Mesquita Filho", Avenida Engenheiro Luiz Edmundo Carrijo Coube, 14-01, \\ TROPICALCEP 17033-360, Bauru, São Paulo, Brazil \\ ${ }^{\mathrm{b}}$ Environmental Research and Innovation Department - Luxemburg Institute of Science and Technology, 5, Avenue des Hauts-Fourneaux, L-4362, \\ Esch-Sur-Alzette, Luxemburg, Brazil \\ ${ }^{\mathrm{c}}$ Instituto de Geociências e Ciências Exatas, Universidade Estadual Paulista “Julio de Mesquita Filho", Avenida 24-A, 1515, CEP 13506-900, Rio Claro, São \\ Paulo, Brazil \\ d Centro de Energia Nuclear na Agricultura (CENA), Universidade de São Paulo, Avenida Centenário, 303, CEP 13416-970, Piracicaba, São Paulo, Brazil
}

\section{A R T I C L E I N F O}

\section{Article history:}

Received 10 May 2016

Received in revised form

19 July 2016

Accepted 3 August 2016

Available online 9 August 2016

\section{Keywords:}

Fine suspended sediments

Natural vs. anthropogenic sources

Polluted river basin

Brazil

\begin{abstract}
A B S T R A C T
Approximately $40 \%$ of the volume of domestic sewage generated in the São Paulo State is untreated and released into water bodies, causing serious pollution problems that affect the water quality and especially the suspended sediments transported by rivers. Thus, this paper investigates the seasonal influence on the origin and fluxes of $\mathrm{Cu}, \mathrm{Co}, \mathrm{Cr}, \mathrm{Zn}, \mathrm{Cd}, \mathrm{Ni}, \mathrm{Sc}$ and particulate organic matter (POM) in sediments transported by a disturbed watershed in the São Paulo State, i.e. the Sorocaba River basin. POM was characterized using particulate organic carbon, particulate organic nitrogen, $\mathrm{C}: \mathrm{N}$ ratio and $\delta^{13} \mathrm{C}$ and $\delta^{15} \mathrm{~N}$ stable isotopic composition. Eight sample collections of fine suspended sediments (FSS) were carried out at the mouth of the Sorocaba River from July 2009 to May 2010. During the study period, the discharge rate followed the seasonal variation trend of the past 25 years. $Z n$ was the most abundant trace element in the FSS, followed by $\mathrm{Cr}, \mathrm{Cu}, \mathrm{Ni}, \mathrm{Co}, \mathrm{Sc}$ and $\mathrm{Cd}$. There was a higher concentration of trace elements during the dry season, except for Sc and Co, which did not vary seasonally. The POM showed the same trend, with higher concentrations during the dry season. The calculated enrichment factors and geoaccumulation index indicated that most of the trace elements are of geogenic origin, except for $\mathrm{Zn}$, which showed significant anthropogenic contributions (55\%). The elemental and isotopic analysis of $\mathrm{C}$ and $\mathrm{N}$ and $\mathrm{C}: \mathrm{N}$ ratio indicated that the anthropogenic origin of POM found in the FSS is related mainly to domestic sewage (97\%), while the significant correlation found between the concentrations of $\mathrm{Zn}$ and POM indicates that the main anthropogenic source of $\mathrm{Zn}$ is related to this domestic sewage. The FSS load transported during the study period was of $373,194 \mathrm{t} \mathrm{y}^{-1}$, of which $87 \%$ occurred during the rainy season.
\end{abstract}

() 2016 Elsevier Ltd. All rights reserved.

\section{Introduction}

Trace elements (elements with concentration lower than $1000 \mathrm{ppm}$ ) are naturally occurring in varying concentrations in the

\footnotetext{
* This paper has been recommended for acceptance by W. Wen-Xiong.

* Corresponding author. Avenida 24-A, n 1515, C. P. 178, CEP 13506-900, Bela Vista, Rio Claro, São Paulo, Brazil.

E-mail addresses: alefernandes1966@yahoo.com.br (A.M. Fernandes), christophe.hissler@list.lu (C. Hissler), ftomazini@rc.unesp.br, ftomazini@rc.unesp. br (F.T. da Conceição), ederspatti@hotmail.com (E.P. Spatti Junior), jmortatt@cena. usp.br (J. Mortatti).
}

lithosphere, hydrosphere, atmosphere and living organisms. The distribution, natural mobility and availability of these elements depend on the physical and chemical conditions and on the biological processes in the environment (Gaillardet et al., 2003; Kucuksezgin et al., 2008). Since the beginning of the industrial revolution, human activities have altered the geochemical cycle of trace metals and increased their distributions in different environmental systems. Soils and river sediments are the main recipients in terrestrial and aquatic ecosystems (Viers et al., 2009). In addition to other important sources (fertilizers and pesticides used in agriculture), domestic and industrial wastewater discharges and 
the sludge from sewage treatment plants are the main sources of trace metals in river water and groundwater (Nriagu, 1988).

Since the study of Martin and Meybeck (1979), which showed that the composition of suspended matter transported by the world's largest rivers, there has been a growing interest to estimate suspended sediment transport in rivers and the elements/chemical compounds associated with them (Horowitz, 2008; Walling, 2013). Some studies stand out for using the comparison of a reference geochemical background, through the calculation of enrichment factors (EF) in bottom sediments (Alves et al., 2010; Amorim et al., 2009; Cotta et al., 2006; Gaillardet et al., 2003; Harikumar and Jisha, 2010; Hissler and Probst, 2006a, 2006b; Kendall and Doctor, 2003; Kersten and Forstner, 1995; Meybeck et al., 2007; Miller et al., 2007; Mortatti et al., 2012; Mozeto et al., 2003; Nasrabadi et al., 2010; Salomons and Forstner, 1984; Shotyk et al., 2000) as well as in suspended sediments (Hissler and Probst, 2006a, 2006b; Kucuksezgin et al., 2008; Mortatti and Probst, 2010; Ollivier et al., 2011; Radakovich et al., 2008; Viers et al., 2009; Woitke et al., 2003).

Particulate organic matter in river sediments is characterized as a mixture from different sources (Barros et al., 2010; Berto et al., 2013; Finlay and Kendall, 2007; Gao et al., 2012; Kendall et al., 2001; Moreira-Turq et al., 2013; Sarma et al., 2012; Tamooh et al., 2012 ) and its origin can be investigated by analyzing its $C$ and $N$ stable isotopic composition $\left(\delta^{13} \mathrm{C}\right.$ and $\delta^{15} \mathrm{~N}$, respectively) and its $\mathrm{C}: \mathrm{N}$ ratio (Gao et al., 2012). For instance, the $\delta^{13} \mathrm{C}$ isotopic composition of various natural particulate organic matter ranges from -42 to $-24 \%$ oo phytoplankton, -32 to $-22 \%$ for terrestrial plants of C3 photosynthetic cycle and -16 to $-9 \%$ oo for terrestrial plants of C4 photosynthetic cycle, whereas $\delta^{15} \mathrm{~N}$ and C:N ratios range from -15 to $+20 \%$ and 5 to 8 for phytoplanktons and from +3 to $+7 \%$ and 15 to 50 for terrestrial plants of C3 and C4 photosynthetic cycle (Kendall et al., 2001). For the anthropogenic contribution related to domestic sewage the $\delta^{13} \mathrm{C}, \delta^{15} \mathrm{~N}$ and $\mathrm{C}: \mathrm{N}$ ratios range from -26 to $-22 \%$, from +7 to $+22 \%$ oo and from 7 to 11, respectively (Barros et al., 2010; Gao et al., 2012; Mayer et al., 2002). In Brazil, the few studies that have evaluated the origin and fluvial fluxes of suspended sediment were conducted in the São Paulo State (Alves et al., 2010; Cotta et al., 2006; Fernandes et al., 2012; Mortatti and Probst, 2010; Mortatti et al., 2012). However, none of these studies have associated suspended sediments to particulate organic matter, with POM was only studied in the Piracicaba River basin, also located in the São Paulo State (Krusche et al., 2002), and in the Guanabara Bay, in Rio de Janeiro State (Carreira et al., 2002) and Babitonga Bay, in Santa Catarina State (Barros et al., 2010).

Few studies have been carried out to explain the origin and flux of trace elements and particulate organic matter in suspended sediments in tropical watersheds, which can lead to an incorrect interpretation. Thus, the main purpose of the study was to assess the advantages of combined analysis of trace elements $(\mathrm{Cu}, \mathrm{Co}, \mathrm{Cr}$, $\mathrm{Zn}, \mathrm{Cd}, \mathrm{Ni}$ and Sc) with particulate organic matter (POM) - through particulate organic carbon (POC), particulate organic nitrogen (PON), the C:N ratio and the stable isotopes $\delta^{13} \mathrm{C}$ and $\delta^{15} \mathrm{~N}-$ in order to identify their natural and anthropogenic sources in a tropical environment. In this context, the Sorocaba River basin is an ideal study area, since this region is an important regional development cluster in the São Paulo State, which has a population of 1.2 million inhabitants and a diversified industrial park consisting of 1850 enterprises, where approximately $82 \%$ of urban wastewater discharged directly into water bodies, without treatment (IBGE, 2010; IPT, 2006). The results provide new insight into the relative importance of combined analysis on the environmental impact assessment related to different sources of trace elements and particulate organic matter in disturbed watersheds.

\section{Characterization of study area}

The Sorocaba River, the most important left bank tributary of the Tietê River, runs $227 \mathrm{~km}$ northwest to its confluence with the Tiete River (Fig. 1A). Located in the southeastern portion of the São Paulo State, Brazil, between latitudes 23 and $24^{\circ} \mathrm{S}$ and longitudes 47 and $48^{\circ} \mathrm{W}$, its drainage basin occupies an area of $5269 \mathrm{~km}^{2}$ and covers 18 municipalities with a total population of approximately 1.2 million inhabitants. The Sorocaba River basin has a diversified industrial park that consists of about 1850 enterprises, particularly the textile, mechanical, metallurgical, food, tanning sectors and sugarcane rum mills (IBGE, 2010; IPT, 2006).

According to IPT (2006), the Sorocaba River basin has a Cwa climate, i.e. hot and humid in summer and dry in winter, with an average annual temperature of 18 to $22^{\circ} \mathrm{C}$. The monthly and annual mean historical rainfall data between 1984 and 2008, obtained from the DAEE (2010) for the Pluviometric station E4-019 $\left(23^{\circ} 20^{\prime} \mathrm{S}\right.$, $47^{\circ} 41^{\prime} \mathrm{W}$ ), located in the central region of the Sorocaba River basin, showed that the average annual rainfall in the basin was $1243 \mathrm{~mm}$, in which January was the wettest (average of $243 \mathrm{~mm}$ ) and August the driest month (average of $27 \mathrm{~mm}$ ) (Fig. S1A). During the study period (July 2009 to May 2010), the rainfall was much higher than the historical average (Fig. S1A), i.e., $2047 \mathrm{~mm}$, in which the months of January $2010(458 \mathrm{~mm})$ and June $2010(27 \mathrm{~mm})$ had the highest and lowest rainfall, respectively.

The mean monthly discharge data for the Sorocaba River for this same time period (1984-2008) were also provided by DAEE (2010) for the Fluviometric station $4 \mathrm{E}-001\left(23^{\circ} 01^{\prime} \mathrm{S}, 47^{\circ} 48^{\prime} \mathrm{W}\right)$, located at the mouth of the Sorocaba River in the municipality of Laranjal Paulista. The year of 1991 was the year with the highest average discharge $\left(100 \mathrm{~m}^{3} \mathrm{~s}^{-1}\right)$, coinciding with the highest rainfall index (1622 mm) in these 25 years. February was the month with the highest average discharge $\left(127 \mathrm{~m}^{3} \mathrm{~s}^{-1}\right)$, while the lowest average was in September $\left(37 \mathrm{~m}^{3} \mathrm{~s}^{-1}\right.$ ) (Fig. S1B), which is the month with the least amount of rain, according to the rainfall data. Due to the higher levels of rainfall in the study period, the average discharge rate of the Sorocaba River $\left(157 \mathrm{~m}^{3} \mathrm{~s}^{-1}\right)$ was also higher than the historical average $\left(63 \mathrm{~m}^{3} \mathrm{~s}^{-1}\right)$, with the highest value in January $\left(358 \mathrm{~m}^{3} \mathrm{~s}^{-1}\right)$ and the lowest in June $\left(58 \mathrm{~m}^{3} \mathrm{~s}^{-1}\right)$ (Fig. S1B). The discharge showed a significant positive linear correlation for rainfall, either with the historical series data or for the study period data.

The drainage basin of the Sorocaba River includes two geomorphological units: Plateaus and hills of the east-southeast Atlantic Ocean and Peripheral Depression of the eastern border of the Paraná Basin (Ross, 1996; Ross and Moroz, 1997). The first unit is associated with metamorphic rocks belonging to the São Roque Group and the Embu Complex and their associated granites. It is made up of convex hilltops (altitudes ranging between 800 and $1000 \mathrm{~m}$ ) and deep valleys (slope above 20\%), which characterize a high drainage density. The second geomorphological unit was formed in the area where the rocks of the Paraná Sedimentary Basin protrude. It is formed by hills with tabular and large convex tops, having predominant altitudes between 600 and $700 \mathrm{~m}$ and slopes ranging between 5 and $10 \%$.

The predominant soils in the drainage basin are Ultisols and Oxisols, according to USDA (1999) nomenclature, corresponding to Red Argisol (49\%), Red Latosol (38\%) and Red-Yellow Latosol (9\%) in the Brazilian soil classification (EMBRAPA, 2013; Oliveira et al., 1999). The original vegetation that covered these soils was characterized by forests, brushwood, fields, and lowland savanna vegetation. However, most of the vegetation along this basin has been removed for agricultural occupation and urbanization processes. The land use in the Sorocaba River basin is currently occupied by anthropogenic pastures and fields (77\%), followed by areas 

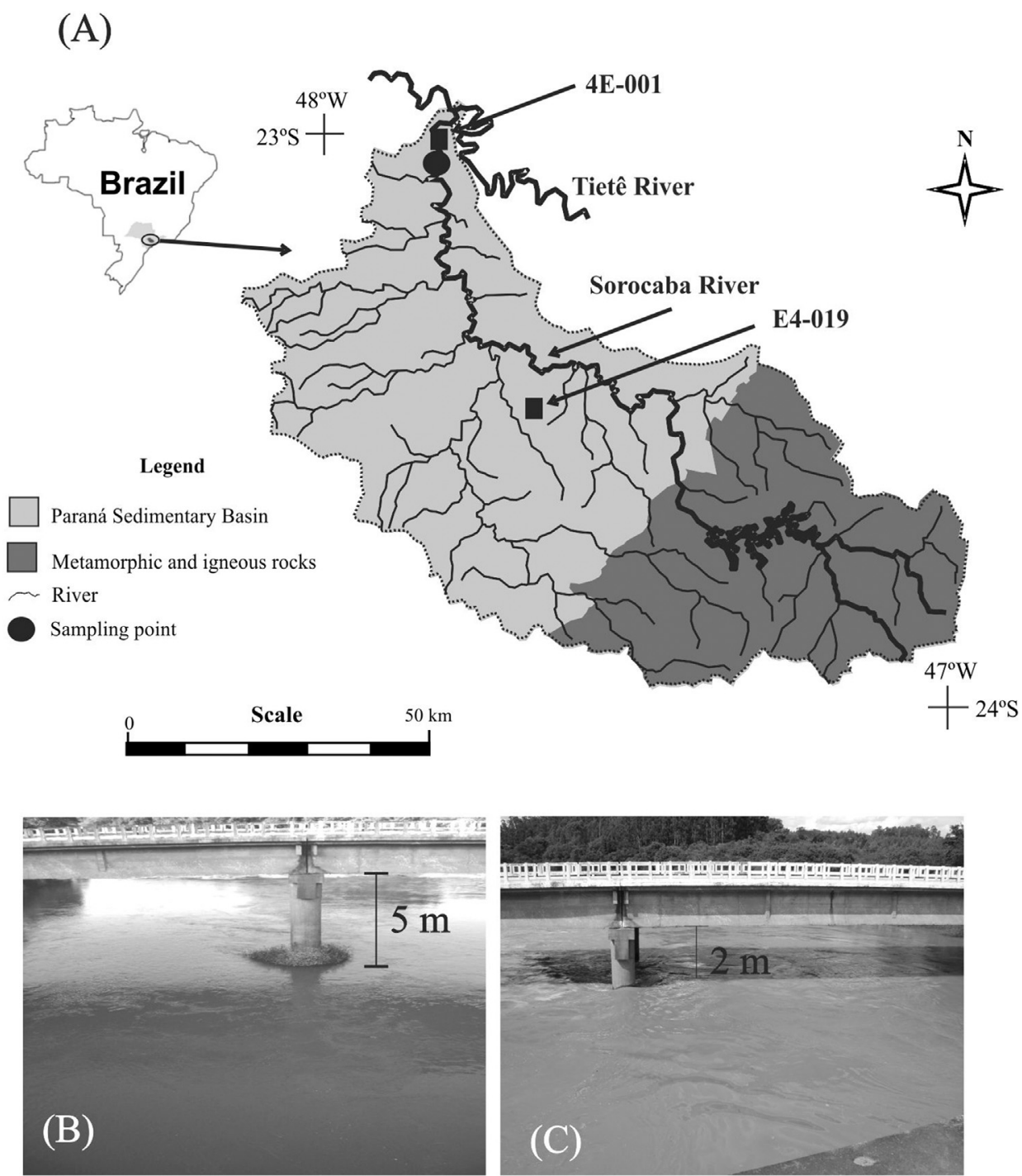

Fig. 1. The Sorocaba River basin with the location of sampling point (A), highlighting the fluviometric (E4-001) and pluviometric (4E-019) Stations. View of the sampling location during the dry season in July 2009 (B) and the rainy season in January 2010 (C).

with agricultural crops (14\%), reforestation areas (3\%), remnants of natural vegetation cover (2\%) and urban areas (4\%) (IPT, 2006).

\section{Materials and methods}

\subsection{Sample collection}

Eight sample collections of suspended sediment were carried out at the Sorocaba River mouth, in the municipality of Laranjal Paulista, from July 2009 to May 2010. The study period covered all stages of hydrograph: rising, high, falling and low waters of the Sorocaba River (Fig. S1B). The fine suspended sediment concentration (FSS, fine sediment fraction $<63 \mu \mathrm{m}$ ) in the Sorocaba River water at each collection was determined from $1000 \mathrm{~mL}$ of river water, sampling at the main current axis, always $1.5 \mathrm{~m}$ deep, using a simple stage sampler (Mortatti, 1995). After filtering $300 \mathrm{~mL}$ of sample in $0.45 \mu \mathrm{m}$ cellulose membrane previously dried and weighed, and dried at $60{ }^{\circ} \mathrm{C}$ to constant weight, the FSS concentration was quantified by the gravimetric method (APHA, 1999).

\subsection{Chemical and isotopic analysis}

The FSS samples for the chemical analyses were obtained by pumping river water into polypropylene containers (30 L), always at $1.5 \mathrm{~m}$ deep. After the decanting period of 7 days and draining the supernatant, the sediments were recovered, air-dried at ambient temperature and ground in an agate mortar, and the fine sediment fraction $(<63 \mu \mathrm{m})$ was separated by sieving with a nylon sieve. Each sample was calcined at $1000{ }^{\circ} \mathrm{C}$ to eliminate the organic matter. Next, the samples were submitted to chemical extraction by the alkaline fusion method at $1000{ }^{\circ} \mathrm{C}$ for $30 \mathrm{~min}$, with lithium tetraborate and lithium metaborate $(2: 1)$ in a platinum crucible doped with gold (5\%) (Samuel et al., 1985). After cooling, the molten material was solubilized in $20 \mathrm{~mL}$ of $\mathrm{HCl}(1 \mathrm{M})$, under stirring and heating $\left(40{ }^{\circ} \mathrm{C}\right)$, and the volume was completed to $50 \mathrm{~mL}$ with ultrapure water of low electrical conductivity (lower than $0.02 \mu \mathrm{S} \mathrm{cm}^{-1}$ ). The purity of the chemical reagents was controlled using analytical blanks, which were prepared only with lithium tetraborate and lithium metaborate (2:1), following the same solubilisation method described. 
All samples were analyzed in triplicate and the chemical species of interest were quantified by inductively coupled argon plasma optical emission spectrometry (ICP-OES Optima 3000 DV), with the following limits of determination for the trace elements $\left(\mu \mathrm{g} \mathrm{L}^{-1}\right)$ : $\mathrm{Cu}$ (5), $\mathrm{Co}(5), \mathrm{Cr}(10), \mathrm{Zn}(20), \mathrm{Cd}(5), \mathrm{Ni}(5)$ and Sc (10). The international reference material Soil-7 of the International Atomic Energy Agency (IAEA) was used for quality control and showed the following average recovery percentage for extraction and analysis in triplicate: $\mathrm{Cu}$ (94\%), $\mathrm{Co}$ (95\%), $\mathrm{Cr}$ (92\%), Zn (103\%), Ni (97\%) and Sc (98\%). The $\mathrm{Cu}, \mathrm{Co}, \mathrm{Cr}, \mathrm{Zn}, \mathrm{Cd}, \mathrm{Ni}$ and $\mathrm{Sc}$ discharge weighted averages $\left(C_{D W A}\right)$ were obtained according to Equation (1).

$C_{D W A}=\frac{\sum_{i=1}^{n} C_{i} Q_{i}}{\sum_{i=1}^{n} Q_{i}}$

where $C_{i}$ is the concentration in the sample $i\left(\mathrm{mg} \mathrm{L}^{-1}\right)$ and $Q_{i}$ is the instantaneous discharge rate measured during the collection of the sample $i\left(\mathrm{~m}^{3} \mathrm{~s}^{-1}\right)$.

The percentage of particulate organic carbon (POC) and particulate organic nitrogen (PON) and their respective $\delta^{13} \mathrm{C}$ and $\delta^{15} \mathrm{~N}$ isotopic signatures were determined by gas chromatography using an Automatic Nitrogen and Carbon Analyzer (ANCA-GSL Sercon Hydra 20-20), with the direct combustion of FSS samples. The stable isotope ratios ( $\%$ oo were obtained through Equation (2). The international PDB standard (Cretaceous carbonate fossil Bellemnitella americana from Peedee Formation in South Carolina, USA) and the atmospheric $\mathrm{N}_{2}$ were used for $\delta^{13} \mathrm{C}$ and $\delta^{15} \mathrm{~N}$ (Barrie and Prosser, 1996), respectively. The standard deviations in the isotopic analysis were $0.2 \%$ for $\delta^{13} \mathrm{C}$ and $0.3^{\circ} \%$ for $\delta^{15} \mathrm{~N}$. The particulate organic matter content was calculated by multiplying the POC by 1.72 , assuming that the carbon proportion in the average organic matter composition is $58 \%$ for tropical and subtropical soils (Santos and Camargo, 1999).

$\delta^{N} E=\left(\frac{R_{\text {sampling }}}{R_{\text {standard }}}-1\right) 1000$

where $\mathrm{N}$ is a heavy isotope of the element $\mathrm{E}$ and $\mathrm{R}$ is the abundance ratio of the heavy to light isotopes $\left({ }^{13} \mathrm{C} /{ }^{12} \mathrm{C},{ }^{15} \mathrm{~N} /{ }^{14} \mathrm{~N}\right)$ of that element.

\subsection{Natural and anthropogenic sources}

The calculation of enrichment factors (EF) relative to a natural geochemical background has been used as a measure of geochemical trends to compare areas and to identify trace element origin (Harikumar and Jisha, 2010; Zhang and Liu, 2002) and contamination (Miller et al., 2007; Woitke et al., 2003). Equation (3) was used to calculate the EF in the Sorocaba River basin, using Sc as the normalizing element, since it normally presents a conservative behaviour over the time.

$E F=\frac{\left(M_{i} / S c\right)_{\text {sample }}}{\left(M_{i} / S c\right)_{\text {ref }}}$

where $\left(M_{i} / S c\right)_{\text {sample }}$ is the ratio between the concentration of the trace element of interest $\left(M_{i}\right)$ and Sc in the FSS sample and $\left(M_{i} / S c\right)_{\text {ref }}$ corresponding to ratio between the concentration of the trace element of interest $\left(M_{i}\right)$ and Sc of the reference geochemical background used.

To assess the degree of pollution of the trace elements studied in the Sorocaba River basin, the geoaccumulation index $\left(I_{g e o}\right)$ introduced by Müller (1979) was used (Equation (4)).
$I_{\text {geo }}=\log 2 \cdot\left([M]_{\text {sed }} / 1.5 \cdot[M]_{\text {background }}\right)$

where $[M]_{\text {sed }}$ is the concentration of trace element $M$ in the FSS and $[M]_{\text {background }}$ is the concentration of the same trace element $M$ in the geochemical background reference.

\subsection{Statistical analysis}

Pearson correlation analysis was applied to establish the relationship between trace elements and particulate organic matter. Another way to confirm the hypothesis that was suggested using Pearson correlation analysis was to use two different multivariate statistical approaches. The first methodology is the Cluster Analysis (CA) in r-mode (results cluster variables) that was performed using Ward's hierarchical agglomerative method (unweighted pair-group method, UPGM) and the squared Euclidean distance measured. The second statistical treatment applied to the same ranked data set was the Principal Components Analysis (PCA), which is an ordination method utilizing values and vectors from a variancecovariance matrix.

\section{Results}

The river discharge and FSS, $\mathrm{Cu}, \mathrm{Co}, \mathrm{Cr}, \mathrm{Zn}, \mathrm{Cd}$, Ni and Sc concentrations, with their respective discharge weighted averages $\left(C_{D W A}\right)$ are presented in Table 1 . Despite the higher discharges achieved for the sample period, when compared with the historical series (Fig. S1B), the temporal distribution of the river discharge during the study period followed the seasonal variation that characterizes the dry (April to September) and rainy (October to March) seasons. The average discharge rate during the sampling period was of $169.0 \mathrm{~m}^{3} \mathrm{~s}^{-1}$, with the highest value obtained in January 2010 $\left(366.5 \mathrm{~m}^{3} \mathrm{~s}^{-1}\right)$ and the lowest in July $2009\left(37.5 \mathrm{~m}^{3} \mathrm{~s}^{-1}\right)$. As expected, the discharge in the rainy season was higher than in the dry season by more than 3 times (Fig. 1B-C).

The FSS concentration proved to be influenced by seasonal discharge variations, which was higher in the rainy season when compared with the dry season, with discharge-weighted average of $70.0 \mathrm{mg} \mathrm{L}^{-1}$. This increase is mainly related to the erosion of the surface soil layers of the Sorocaba River basin during the rainy season and the surface runoff carrying particulate matter to the watercourses. Pearson's linear correlation between the discharge and the FSS concentration during the study period $(r=0.92$, $P<0.01$ ) was illustrated in Fig. S2, obtaining an equation to quantify the FSS concentration from the discharge river $(\mathrm{FSS}=0.21 \mathrm{Q}+15.42)$.

The discharge weighted average concentrations of trace

Table 1

Sorocaba River discharge, FSS concentrations and $\mathrm{Cu}, \mathrm{Co}, \mathrm{Cr}, \mathrm{Zn}, \mathrm{Cd}$, Ni and Sc particulate concentrations in the Sorocaba River during the sampling campaigns. The respective weighted averages values for the entire study $\left(C_{D W A}\right)$.

\begin{tabular}{|c|c|c|c|c|c|c|c|c|c|}
\hline \multirow[t]{2}{*}{ Sampling } & \multirow{2}{*}{$\frac{\text { Discharge }}{\mathrm{m}^{3} \mathrm{~s}^{-1}}$} & \multirow{2}{*}{$\frac{\mathrm{FSS}}{\mathrm{mg} \mathrm{L}^{-1}}$} & $\mathrm{Cu}$ & Co & $\mathrm{Cr}$ & $\mathrm{Zn}$ & $\mathrm{Cd}$ & $\mathrm{Ni}$ & Sc \\
\hline & & & \multicolumn{7}{|c|}{$\mu \mathrm{g} \mathrm{g}^{-1}$} \\
\hline $07 / 09$ & 37.5 & 14.3 & 28 & 15 & 59 & 552 & 14 & 25 & 12 \\
\hline $09 / 09$ & 99.8 & 45.3 & 33 & 18 & 61 & 323 & 11 & 25 & 14 \\
\hline $10 / 09$ & 123.2 & 54.3 & 31 & 18 & 68 & 284 & 10 & 25 & 13 \\
\hline $12 / 09$ & 363.3 & 87.2 & 23 & 20 & 57 & 190 & 10 & 19 & 13 \\
\hline $01 / 10$ & 366.5 & 101.5 & 29 & 17 & 58 & 207 & 12 & 25 & 15 \\
\hline $02 / 10$ & 184.0 & 37.8 & 28 & 19 & 57 & 186 & 10 & 25 & 14 \\
\hline $04 / 10$ & 107.6 & 51.0 & 30 & 17 & 74 & 393 & 11 & 25 & 15 \\
\hline $05 / 10$ & 70.2 & 22.7 & 36 & 23 & 83 & 447 & 13 & 28 & 15 \\
\hline$C_{D W A}$ & 169.0 & 70.0 & 28 & 18 & 61 & 252 & 10 & 24 & 14 \\
\hline
\end{tabular}


elements during the study period showed a greater abundance of $\mathrm{Zn}\left(252 \mu \mathrm{g} \mathrm{g}^{-1}\right)$, followed by $\mathrm{Cr}\left(61 \mu \mathrm{g} \mathrm{g}^{-1}\right), \mathrm{Cu}\left(28 \mu \mathrm{g} \mathrm{g}^{-1}\right)$, Ni $\left(24 \mu \mathrm{g} \mathrm{g}^{-1}\right), \mathrm{Co}\left(18 \mu \mathrm{g} \mathrm{g}^{-1}\right), \mathrm{Sc}\left(14 \mu \mathrm{g} \mathrm{g}^{-1}\right)$ and $\mathrm{Cd}\left(10 \mu \mathrm{g} \mathrm{g}^{-1}\right)$, and this order of abundance remained during the dry and rainy seasons. The concentrations of Sc and Co presented no seasonal variation. However, the seasonal effect was marked by higher concentrations during the dry season compared to the rainy season for $\mathrm{Cu}, \mathrm{Cr}, \mathrm{Zn}$, $\mathrm{Cd}$ and $\mathrm{Ni}$. $\mathrm{Zn}$ was the trace element with the highest seasonal variation, ranging from $552 \mu \mathrm{g} \mathrm{g}^{-1}$ to $186 \mu \mathrm{g} \mathrm{g}^{-1}$. The relation between the concentrations of the studied trace elements and the FSS concentration showed these seasonal trends (Fig. 2). The $\mathrm{Cu}, \mathrm{Cr}, \mathrm{Zn}$, $\mathrm{Cd}$ and Ni concentration decreased with increasing FSS concentration, whereas FSS concentration showed no influence on Sc and Co seasonal concentrations.

Table 2 shows the POC, PON and POM concentrations in the FSS of the Sorocaba River during the study period, with their respective $\delta^{13} \mathrm{C}$ and $\delta^{15} \mathrm{~N}$ isotopic values and $\mathrm{C}: \mathrm{N}$ ratio. The dischargeweighted average concentrations for POC, PON and POM were of $3.3,0.33$ and $5.6 \%$, respectively, with the highest concentrations of POC (4.8\%), PON (0.51\%) and POM (8.2\%) during the dry season in July, which also presented the lowest discharge rates and FSS concentration. There was a significant correlation between the concentrations of POC and PON $(r=0.99$ and $P<0.01)$ throughout the study period, as illustrated in Fig. S3. This figure also shows the POC and PON concentrations in accordance with the river discharge and shows a clear diluting effect of the concentrations of these compounds during the rainy season. The discharge-weighted average of the C: $\mathrm{N}$ ratio was 10.0, ranging between 9.3 and 11.0. The discharge-weighted average values for $\delta^{13} \mathrm{C}$ and $\delta^{15} \mathrm{~N}$ were of -23.00 and $9.71 \%$, respectively, with the highest values obtained in the dry period compared with the rainy season.

\section{Discussion}

\subsection{Origin of particulate organic matter}

The different sources of organic matter in river sediments can be investigated by evaluating the elemental and isotopic $\mathrm{C}$ and $\mathrm{N}$ composition present in the suspended particulate load and then comparing with reference parameters (Kendall and Doctor, 2003; Kendall et al., 2001; Krusche et al., 2002; Walling, 2013). In regions without anthropogenic influence, the organic matter in
Table 2

Concentrations of measured particulate organic carbon (POC), measured particulate organic nitrogen (PON), measured $\delta^{13} \mathrm{C}$ and $\delta^{15} \mathrm{~N}$ and calculated particulate organic matter (POM) and C:N ratio in the FSS transported by the Sorocaba River during the sampling campaigns.

\begin{tabular}{|c|c|c|c|c|c|c|}
\hline \multirow[t]{2}{*}{ Sampling } & POC & $\delta^{13} \mathrm{C}$ & PON & $\delta^{15} \mathrm{~N}$ & POM & $\mathrm{C} / \mathrm{N}$ \\
\hline & $\%$ & $\%$ & $\%$ & $\%$ & $\%$ & \\
\hline $07 / 09$ & 4.8 & -22.85 & 0.51 & +12.72 & 8.2 & 9.4 \\
\hline $09 / 09$ & 3.4 & -23.10 & 0.34 & +9.59 & 5.8 & 9.9 \\
\hline $10 / 09$ & 3.4 & -23.40 & 0.34 & +9.54 & 5.9 & 10.1 \\
\hline $12 / 09$ & 2.8 & -22.58 & 0.25 & +8.64 & 4.8 & 11.0 \\
\hline $01 / 10$ & 2.4 & -22.20 & 0.23 & +8.02 & 4.1 & 10.1 \\
\hline $02 / 10$ & 2.5 & -22.83 & 0.23 & +7.87 & 4.2 & 10.6 \\
\hline $04 / 10$ & 3.1 & -23.74 & 0.31 & +9.15 & 5.3 & 10.0 \\
\hline $05 / 10$ & 3.8 & -23.27 & 0.41 & +12.16 & 6.6 & 9.3 \\
\hline Average & 3.3 & -23.00 & 0.33 & +9.71 & 5.6 & 10.0 \\
\hline
\end{tabular}

suspended sediments may be the contributions from terrestrial organic matter, including plants and soil, which reflect the type of plant supported (C3 or C4), which are carried along with the sediments by erosion processes; and aquatic organisms generally subgrouped into plankton (algae and aquatic microorganisms) and macrophytes (vascular aquatic plants). Each of these sources has a characteristic $\delta^{13} \mathrm{C}$ and $\delta^{15} \mathrm{~N}$ isotopic signature. The $\mathrm{C}$ isotopic fractionation is inherent in the different photosynthetic cycles of terrestrial plants C3 and C4 and freshwater autotrophic organisms such as phytoplankton. The $\mathrm{N}$ isotopic fractionation is related to the different strategies for obtaining $\mathrm{N}$ which fix nitrogen directly from the atmosphere (N-fixing plants) or from assimilation as ammonium/nitrate and involving processes such as volatilization, nitrification and denitrification (non N-fixing plants) (Kendall et al., 2001; Mortatti and Probst, 1998). In disturbed areas the contributions of domestic effluents should also be considered, as verified in Brazilian studies by Krusche et al. (2002) in the Piracicaba River basin (SP), and by Carreira et al. (2002) and Barros et al. (2010) in the Guanabara bay (RJ) and Babitonga bay (SC), respectively. These studies highlighted that the anthropogenic load of organic matter changed the quantity and quality of the fluvial organic matter compared to the natural environments.

The carbon and nitrogen average concentration and isotopic composition and related $\mathrm{C}: \mathrm{N}$ ratio for the main sources
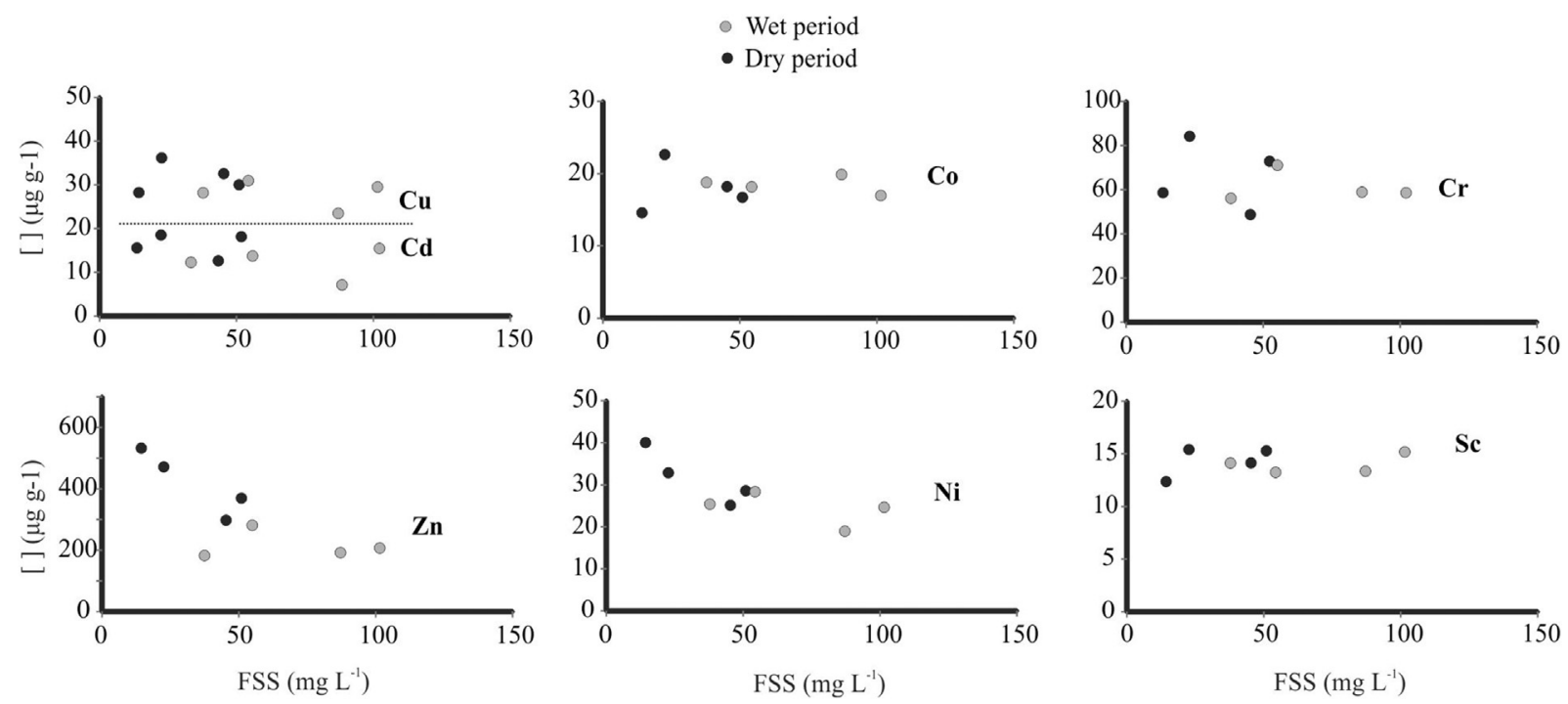

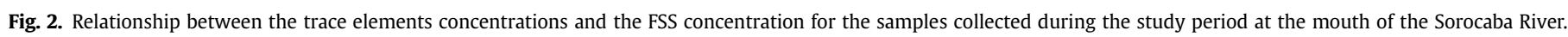


(phytoplankton, C3 and C4 plants and urban sewage) of particulate organic matter in the river systems are presented in Table S1. In the first analysis, the results obtained could be product of a mixture among the main sources, as showed in Fig. 3A. The organic matter that can be found in the predominant soil of the Sorocaba River basin showed characteristics of C4 plants (pastures, fields with grasses and sugar cane crops) (Fig. 3A), indicating no contribution of C3 plants. Besides, the phytoplankton contribution was considered as negligible, because in river water with FSS concentration lower than $100 \mathrm{mg} \mathrm{L}^{-1} \mathrm{POC}$ is mainly composed of particles coming from soil erosion and anthropogenic activities (Meybeck, 1993). Thus, only two sources should be considered, i.e. C4 plant and/or urban sewage.

According to Gao et al. (2012), low values of $\delta^{15} \mathrm{~N}$ in the river POM can be attributed to soil and terrestrial plant contributions. For rivers subject to heavy anthropogenic disturbances, POM is isotopically enriched in heavy nitrogen components, derived from human wastewater and livestock $\left(\delta^{15} \mathrm{~N}\right.$ of $+7 \%$ oo to $+22^{\circ} \%$ oo (Mayer et al., 2002). The average values of $\delta^{15} \mathrm{~N}$ measured in the POM of the Sorocaba River $(+9.71 \%$ oo in the study period $)$ are closer to the average values assigned to human wastewater and livestock (Fig. 3B). However, the complexity of the nitrogen cycle and the
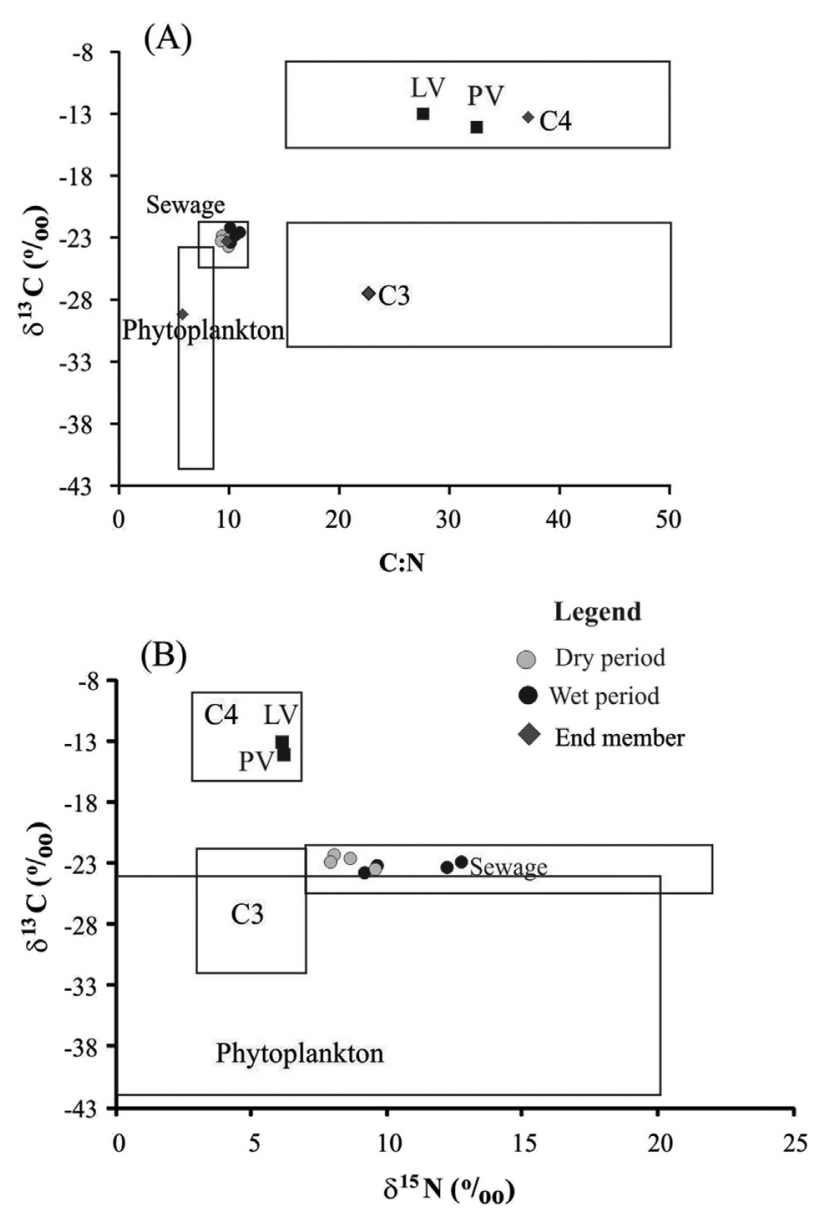

Fig. 3. Plot of $\mathrm{C}: \mathrm{N}$ ratio $v s . \delta^{13} \mathrm{C}$ values of $\mathrm{POC}$, including characterization of the predominant soils in the Sorocaba River basin, i.e. red Argisol (PV) and red Latosol (LV) (Fernandes, 2012) (A), and $\delta^{15} \mathrm{~N} v s . \delta^{13} \mathrm{C}$ values of PON and POC, respectively (B). The characteristic range of stable isotopic compositions and the $\mathrm{C}: \mathrm{N}$ ratio for phytoplankton, C3 and C4 plants were obtained in Kendall et al. (2001); with their endmembers described by Krusche et al. (2002). The urban sewage ranges of $\delta^{13} \mathrm{C}$ and C:N ratio and $\delta^{15} \mathrm{~N}$ were obtained in Gao et al. (2012) and Mayer et al. (2002), with endmembers for $\delta^{13} \mathrm{C}$ and C:N ratio presented in Krusche et al. (2002) (see these values in Table S1). high number of $\mathrm{N}$ isotopic fractionation processes related to ammonification, nitrification, denitrification and nutrient assimilation reactions in the recycling of particulate nitrogen compounds, do not allow the direct use of $\delta^{15} \mathrm{~N}$ as an unequivocal indication of the origin of the particulate organic matter in the river (Carreira et al., 2002; Gao et al., 2012).

In order to provide a quantitative assessment of the contribution of the main sources of POM found in the Sorocaba River, a mixed model was used, assuming as end-members both the terrestrial organic matter and the domestic sewage (Equation (5)). This model was first described by Calder and Parker (1968), and adapted to the marine conditions affected by autogenous organic carbon (Gao et al., 2012). In this work, this model was adapted to the riverine conditions affected by human activities by replacing the marine contribution with domestic sewage. The natural contribution from terrestrial organic matter $(f)$ and the anthropogenic contribution from domestic sewage $\left(f^{\prime}\right)$ were gained using Equations (5) and (6), respectively.

$f(\%)=\frac{\left(\delta^{13} C_{S W}-\delta^{13} C_{S A}\right)}{\left(\delta^{13} C_{S W}-\delta^{13} C_{S T}\right)} \cdot 100$

$f^{\prime}(\%)=100-f$

where $\delta^{13}$ Cis the mean value of the isotopic composition of carbon in the sample $\left(C_{S A}\right)$ and in both end-members, the terrestrial organic matter $\left(C_{S T}\right)$ and the domestic sewage $\left(C_{S W}\right)$.

The $\delta^{13} \mathrm{C}$ average of soils in the Sorocaba River basin was used to represent the end-member terrestrial organic matter $\left(\delta^{13} C_{S T}=-13.55 \%\right.$ \% (Fernandes, 2012). For the end-member domestic sewage, it was used the value of $-23.30 \%$ obtained by Krusche et al. (2002) for the Piracicaba River basin (another large river of the Paraná River Basin). Thus, the larger contribution was attributed to the domestic sewage for the entire study period (97\%). A little difference could be observed between the dry season (99\%) and the rainy season (94\%). These values show that throughout the study period the major part of the POM that is transported by the Sorocaba River was of anthropogenic origin due to the release of untreated urban sewage into the river. The Sorocaba River basin has approximately $1,200,000$ inhabitants who generate a daily load of 54 tons of BOD (biochemical oxygen demand) for only $17.5 \%$ of sewage treatment (IPT, 2006). Moreover, the FSS organic matter characteristics (POC, PON, $\delta^{13} \mathrm{C}, \delta^{15} \mathrm{~N}, \mathrm{C}: \mathrm{N}$ ratio) measured during the study period were similar to the reference values for domestic sewage (Table S1). Consequently, the main source of particulate organic matter found in the FSS of the Sorocaba River during the study period can be related to the load of domestic sewage released into the rivers of the drainage basin.

\subsection{Sources of trace elements and environmental problems}

In fluvial ecosystems the trace elements are present in the solid, dissolved and labile phases, however, even for the most mobile elements, the dominant form of transport occurs in suspended sediment particles (Gaillardet et al., 2003; Hissler and Probst, 2006a, 2006b; Hissler et al., 2015a; Kucuksezgin et al., 2008). The trace element concentrations in the suspended sediment particle depend on their mineralogical composition, grain size and organic matter content, which can be related to their source (natural or anthropogenic), as well as the fluvial environment in which they are transported (Harikumar and Jisha, 2010; Walling, 2005). The particulate fraction of the riverine trace elements is composed of primary and secondary minerals and amorphous materials such as 
iron and manganese oxyhydroxides complexed with organic matter and/or adsorbed on clay particles or iron and manganese oxyhydroxides (Leleyter and Probst, 1999; Tessier et al., 1979; Tessier and Campbell, 1987).

The EF calculation often involves the use of natural geochemical background associated with global average values, such as surface river sediments (Martin and Meybeck, 1979) or Earth's Crust average abundance (Taylor and McLennan, 1995). However the results should be carefully evaluated. High trace element concentrations in river sediments do not necessarily reflect anthropogenic contributions, since these concentrations can be the result of naturally enriched soils and bedrocks relative to global references (Hissler et al., 2015b; N'guessan et al., 2009; Viers et al., 2009). To avoid this problem, the use of regional or even local natural reference values has been discussed and recommended for studies of trace element concentrations in river sediments (Ferrand et al., 1999; Harikumar and Jisha, 2010; Mortatti et al., 2012; Mozeto et al., 2003; Rodrigues and Nalini Junior, 2009). Three reference values were used to calculate the EF in this study (Table S2), the regional values determined for the Tiete River basin (Mortatti et al., 2012), the reference values of global average concentrations reported in the literature for surface river sediments (Martin and Meybeck, 1979) and the average concentration of the Earth's Crust (Taylor and McLennan, 1995).

Martin and Meybeck (1979) related their EF values ranging between 0.7 and 1.5 to natural contributions. Similarly, according to Zhang and Liu (2002), in many studies it was agreed that $0.5<\mathrm{EF}<1.5$ are indicatives of natural contribution and for $\mathrm{EF}>1.5$ a significant percentage of the element comes from other sources, such as the biota and anthropogenic pollution. Fixed values for EF have been also used to differentiate natural contributions from anthropogenic sources, such as 1.0 (Miller et al., 2007; Viers et al., 2009), 1.5 (Harikumar and Jisha, 2010) and 2.0 (Hissler and Probst, 2006a, 2006b; Mukherjee, 2014; Roussiez et al., 2013; Wen et al., 2013; Woitke et al., 2003). In our study it was assumed that for $\mathrm{EF} \leq 1$ the contributions of the trace element studied are natural (soil and rocks erosion processes) and for EF $>1$ the contributions of the trace elements can be related to natural and anthropogenic sources (domestic and industrial effluents).

The EF values of $\mathrm{Zn}, \mathrm{Cu}$ and $\mathrm{Ni}$ were similar for the three different geochemical background (Table 3). Zn present EF always greater than 1 using the regional reference, either during the entire period (2.2), the dry (3.4) or the rainy (1.8) season, indicating different trace element source contributions in the FSS. Cu and $\mathrm{Ni}$ EF were always below 1 indicating that natural $\mathrm{Cu}$ and $\mathrm{Ni}$ mainly contribute to FSS composition. $\mathrm{Co}, \mathrm{Cr}$ and $\mathrm{Cd}$ EF values change according to the geochemical reference that was used. They were slightly higher than 1 for $\mathrm{Co}$ and $\mathrm{Cr}$, whereas $\mathrm{Cd}$ showed the higher EF for this study (from 75.6 to 111.3). The use of global average references for river sediments and Earth's Crust resulted, in general, in increased EF values indicating a greater participation of anthropogenic contributions to the studied trace elements. These differences should be taken into consideration carefully, as

Table 3

Enrichment Factors (EF) obtained for the trace elements present in the FSS transported by the Sorocaba River.

\begin{tabular}{lllllll}
\hline EF & $\mathrm{Cu}$ & $\mathrm{Co}$ & $\mathrm{Cr}$ & $\mathrm{Zn}$ & $\mathrm{Cd}$ & $\mathrm{Ni}$ \\
\hline Regional background $^{\mathrm{a}}$ & 0.7 & 0.5 & 0.5 & 2.2 & 0.9 & 0.3 \\
Surface sediments $^{\mathrm{b}}$ & 0.7 & 1.1 & 0.8 & 3.8 & 100.1 & 0.6 \\
Earth's Crust $^{\mathrm{c}}$ & 0.9 & 1.4 & 1.4 & 2.8 & 78.5 & 0.9 \\
\hline
\end{tabular}

a Mortatti et al. (2012).

b Martin and Meybeck (1979).

c Taylor and McLennan (1995). reported by Viers et al. (2009), especially for Cd, which had a more pronounced increase, with EF values about 100 times higher than those obtained with the regional background. Therefore, considering the regional background as a reference, only $\mathrm{Zn}$ had EF $>1$ values, indicating a possible anthropogenic source for this trace element. To estimate the natural and anthropogenic contributions of $\mathrm{Zn}$ in the FSS of the Sorocaba River, the approach proposed by Shotyk et al. (2000), from the EF equation, was used. The results showed the anthropogenic contribution of $\mathrm{Zn}$ was very high, with an average value of $55.6 \%$ in the study period.

The geoaccumulation index ( $I_{\text {geo }}$ ) was calculated using the regional background given in Table $S 2$. The $I_{g e o}$ index was associated with a qualitative intensity scale of the metal pollution of interest divided into four degrees, i.e. absence of pollution for $I_{g e o}<1$, moderate pollution for $1<I_{\text {geo }}<3$, strong pollution for $3<I_{g e o}<5$ and extreme pollution for $I_{g e o}>5$. As previously shown with the EF calculation, the average of $I_{g e o}$ results obtained for $\mathrm{Cu}(0.4)$, $\mathrm{Co}(0.3)$, $\mathrm{Cr}(0.3), \mathrm{Cd}(0.5)$ and $\mathrm{Ni}(0.2)$ did not indicate any pollution level $\left(I_{g e o}<1\right)$. However, the average of $I_{g e o}$ for $Z n$ was 1.3, corresponding to a moderate degree of pollution. The Sorocaba River basin does not contain any $\mathrm{Zn}$-mining activity, as it could be observed in other river basins (Carvalho et al., 1999; Harikumar and Jisha, 2010; Kucuksezgin et al., 2008; Miller et al., 2007). Moreover, as described in the works of Sardinha et al. (2010) and Fernandes (2012), no mineral fractions that may cause Zn natural enrichment in FSS particles were identified in the soils and bedrocks of the Sorocaba River basin.

Thus, only anthropogenic sources can explain the $\mathrm{Zn}$ excess in FSS in the Sorocaba River basin, which can be related to the material transported in agricultural areas that use fertilizers and pesticides, as seen in other watersheds (Mortatti and Probst, 2010; Roussiez et al., 2013). However, the seasonal behaviour of $\mathrm{Zn}$ showed higher concentration values in the dry period, indicating that the $\mathrm{Zn}$ excess is not associated with use of fertilizers and pesticides in agricultural areas. The Pearson correlation analysis presented a significant correlation between the $\mathrm{Zn}$ and POM ( $\mathrm{r}=0.92$ and $P<0.01-$ Table 4). The Cluster Analysis (CA) resulted in a small dissimilarity between $\mathrm{Zn}$ and POM (Fig. 4A), exhibiting a similar behaviour. The obtained Principal Components Analysis (PCA) results plotted in Fig. $4 \mathrm{~B}$ also confirmed that $\mathrm{Zn}$ and POM have the same ordination, and, therefore a similar behaviour. Thus, these two multivariate statistical approaches are also compatible with the evaluation performed by the use of the Pearson correlation tests. Therefore, the main source of $\mathrm{Zn}$ can be related to the same origin of POM, i.e. the contribution of untreated urban wastewater discharged directly into the water bodies of the Sorocaba River basin.

The CONAMA Resolution No. 344 (BRASIL, 2004) suggests the orienting values for sediment quality guidelines used in Brazil, which provides the maximum concentration limits in sediment quality for the protection of aquatic life due to the possibility of assimilation into the environment and recognized human hazards. The Threshold Effect Level (TEL) represents the concentration below which adverse biological effects are rarely expected to occur and the Probable Effect Level (PEL) defines the level above which adverse effects are expected to occur frequently. The criterion established by this resolution is based in the Canadian Sediment Quality Guideline (CCME, 1995). The TEL reference values for sediment quality guidelines used in Brazil for trace element concentrations ( $\mathrm{Cu}, \mathrm{Cr}, \mathrm{Zn}, \mathrm{Cd}$ and $\mathrm{Ni}$, in $\mu \mathrm{g} \mathrm{g}^{-1}$ ) are 35.5, 37.3, 123.0, 0.6 and 18.0, respectively, and for the PEL are 197.0, 90.0, 315.0, 3.5 and 35.9, respectively (BRASIL, 2004).

Among the studied trace elements, $\mathrm{Cu}$ showed no potential toxic effect, being present at lower concentrations than the TEL values. The concentrations of $\mathrm{Cr}$ and $\mathrm{Ni}$, intermediate to TEL and PEL 
Table 4

Pearson correlation (with $P<0.01$ ) among $\mathrm{Cu}, \mathrm{Co}, \mathrm{Cr}, \mathrm{Zn}, \mathrm{Cd}, \mathrm{Ni}$, Sc and POM transported by the Sorocaba River.

\begin{tabular}{|c|c|c|c|c|c|c|c|c|}
\hline $\mathrm{Cu}$ & & Co & $\mathrm{Cr}$ & $\mathrm{Zn}$ & $\mathrm{Cd}$ & $\mathrm{Ni}$ & Sc & POM \\
\hline $\mathrm{Cu}$ & 1.00 & 0.34 & 0.33 & 0.44 & 0.59 & 0.49 & 0.01 & 0.32 \\
\hline Co & & 1.00 & 0.52 & -0.19 & 0.25 & 0.10 & 0.57 & -0.18 \\
\hline $\mathrm{Cr}$ & & & 1.00 & 0.48 & 0.34 & 0.50 & 0.27 & 0.31 \\
\hline $\mathrm{Zn}$ & & & & 1.00 & 0.56 & 0.50 & -0.47 & 0.92 \\
\hline $\mathrm{Cd}$ & & & & & 1.00 & 0.60 & -0.47 & 0.52 \\
\hline $\mathrm{Ni}$ & & & & & & 1.00 & -0.14 & 0.33 \\
\hline Sc & & & & & & & 1.00 & -0.15 \\
\hline POM & & & & & & & & 1.00 \\
\hline
\end{tabular}
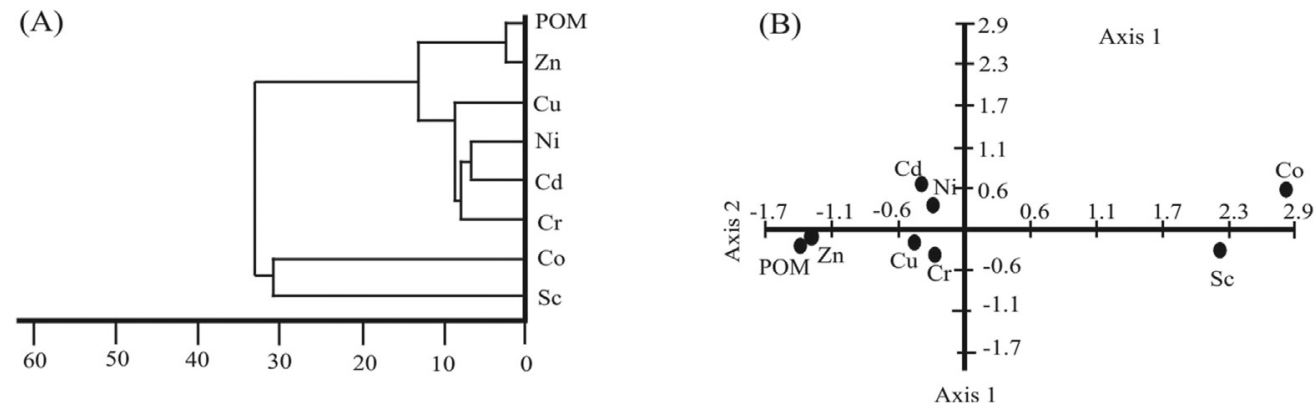

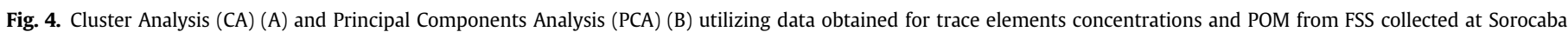
River.

guideline-values, indicated potential toxicity with adverse effects to the biological community. The $\mathrm{Cd}$ and $\mathrm{Zn}$ concentrations were above the PEL limits, and so may indicate adverse biological effects to the aquatic environment and to organisms living in or having direct contact with sediments. The TEL and PEL guideline-values serve as indicators of possible trace element toxicity and their interpretation should be evaluated carefully and together with other indices, since they do not necessarily reflect the regional natural geochemical background and can overestimate or underestimate the degree of toxicity. In addition, a study of trace element speciation, based on progressive and selective chemical extractions, and toxicity tests could provide more information about the (non) incorporation of these micropollutants in FSS and identify their bioavailability to benthic and epibenthic organisms.

\subsection{FSS, trace elements and POM fluxes in the river and seasonal influence}

Understanding the fluvial transport of FSS, trace elements and particulate organic matter is important for the management of the Hydroelectric Power Plant Reservoirs (HPPR), which are of great socio-economic importance in tropical river systems. The contribution of FSS and associated chemical species from the tropical river may compromise the storage capacity and the useful life of this reservoir due to FSS deposition, especially in rainy seasons when water is stored to meet the demand in the dry months of the year. This deposition process can also affect the quality of water and bottom sediments of HPPR due to the load of associated trace elements, which are toxic and depending on the physico-chemical conditions of the environment may become bioavailable, and also the organic load of carbon and nitrogen, which favor its eutrophication process.

Thus, the fluvial transport $\left(\mathrm{T}\right.$ in $\mathrm{t}^{-1}$ ) of FSS, $\mathrm{Cu}, \mathrm{Co}, \mathrm{Cr}, \mathrm{Zn}, \mathrm{Cd}, \mathrm{Ni}$, Sc, POC and PON (Table 5) were calculated according to the stochastic methodology (Probst et al., 1992), expressed by Equation (7). The concentrations of POC and PON (\%) and of trace elements $\left(\mu \mathrm{g} \mathrm{g}^{-1}\right)$ were previously converted to $\mathrm{mg} \mathrm{L}^{-1}$.
Table 5

Particulate fluxes estimated and respective contributions during the dry and the rainy seasons for $\mathrm{FSS}, \mathrm{Cu}, \mathrm{Co}, \mathrm{Cr}, \mathrm{Zn}, \mathrm{Cd}, \mathrm{Ni}, \mathrm{Sc}, \mathrm{POC}$ and PON during the studied period in the Sorocaba River.

\begin{tabular}{llll}
\hline Total transport & Study period $\left(\mathrm{t} \mathrm{y}^{-1}\right)$ & Dry period $(\%)$ & Rainy period (\%) \\
\hline FSS & 373,194 & 13 & 87 \\
$\mathrm{Cu}$ & 10.7 & 15 & 85 \\
$\mathrm{Co}$ & 6.8 & 13 & 87 \\
$\mathrm{Cr}$ & 22.4 & 15 & 85 \\
$\mathrm{Zn}$ & 85.0 & 21 & 79 \\
$\mathrm{Cd}$ & 3.7 & 14 & 86 \\
$\mathrm{Ni}$ & 8.6 & 14 & 86 \\
$\mathrm{Sc}$ & 5.3 & 13 & 87 \\
\hline POC & 10,135 & 16 & 84 \\
PON & 977 & 17 & 83 \\
\hline
\end{tabular}

$T=C_{D W A} \cdot \bar{Q} \cdot f$

where $C_{D W A}=$ average concentration normalized by the discharge rate $\left(\mathrm{mg} \mathrm{L}^{-1}\right), \bar{Q}$ is the average discharge during the study period $\left(\mathrm{m}^{3} \mathrm{~s}^{-1}\right)$ and $f$ is the mass and time correction factor in the calculation of mean fluvial transport, which was equal to 31.536 for results given in tonnes per year.

The FSS load carried by the Sorocaba River in the study period was of $373,194 \mathrm{t} \mathrm{y}^{-1} 87 \%$ of the FSS transport occurred during the rainy season and only $13 \%$ during the dry season, indicating a marked seasonal effect on the FSS transport. Meybeck et al. (2003) proposed a classification, comprising six classes from very low to very high, for the world's rivers based on the ratio between the total fluvial transport of suspended sediments and the drainage area upstream the sampling site. This classification only allows the comparison of specific suspended sediment fluxes, since they are influenced by various factors such as climate, erodibility, degree of surface runoff, slope, type of material (soil and rock), vegetation and the presence of lakes and reservoirs (Meybeck et al., 2003). With a specific transport of approximately $71 \mathrm{t} \mathrm{km}^{-2} \mathrm{y}^{-1}$, the 
Sorocaba River was within the class of rivers with medium sediment transport (18-73 $\mathrm{t} \mathrm{km}^{-2} \mathrm{y}^{-1}$ ), a flux close to that quantified for the rivers Fraser $\left(75 \mathrm{t} \mathrm{km}^{-2} \mathrm{y}^{-1}\right)$ in Canada, Garonne $\left(74 \mathrm{t} \mathrm{km}^{-2} \mathrm{y}^{-1}\right)$ and Lot $\left(74 \mathrm{t} \mathrm{km}^{-2} \mathrm{y}^{-1}\right.$ ) in France, and the Grande $\left(75 \mathrm{t} \mathrm{km}^{-2} \mathrm{y}^{-1}\right)$ and Salt Fork Red $\left(77 \mathrm{t} \mathrm{km}^{-2} \mathrm{y}^{-1}\right.$ ) in the USA (Meybeck et al., 2003). We emphasize that although these rivers present specific FSS flux of the same order of magnitude as the Sorocaba River, all were classified as high sediment transport (73-365 $\mathrm{t} \mathrm{km}^{-2} \mathrm{y}^{-1}$ ) and show no similarity in terms of drainage area, flux and specific water discharge. Regarding the specific transport of suspended sediments in river basins in the São Paulo State, the Sorocaba River had a higher specific load when compared to the Piracicaba and Tietê rivers, which transport 55 and $60 \mathrm{t} \mathrm{km}^{-2}$ $\mathrm{a}^{-1}$ (Bortoletto Junior, 2004), respectively, and are also classified as rivers of medium sediment transport.

The following order was observed for the particulate trace elements fluxes in the Sorocaba River during the study period: $\mathrm{Zn}$ $\left(85 \mathrm{t} \mathrm{y}^{-1}\right)>\mathrm{Cr}\left(22 \mathrm{t} \mathrm{y}^{-1}\right)>\mathrm{Cu}\left(10 \mathrm{t} \mathrm{y}^{-1}\right)>\mathrm{Ni}\left(9 \mathrm{t} \mathrm{y}^{-1}\right)>\mathrm{Co}\left(7 \mathrm{t} \mathrm{y}^{-1}\right)$ $>\mathrm{Sc}\left(5 \mathrm{t} \mathrm{y}^{-1}\right)>\mathrm{Cd}\left(4 \mathrm{t} \mathrm{y}^{-1}\right)$. Regarding seasonality, the highest contribution occurred in the rainy season, during which from 80 to $90 \%$ of the particulate trace elements are transported: $87 \%$ for Co and Sc, $85 \%$ for $\mathrm{Cu}, \mathrm{Cr}, \mathrm{Cd}$ and $\mathrm{Ni}$ and $79 \%$ for $\mathrm{Zn}$. POC $\left(10,135 \mathrm{t} \mathrm{y}^{-1}\right)$ and PON $\left(977 \mathrm{t} \mathrm{y}^{-1}\right)$ fluxes present the same seasonal trend, with the highest percentage transported in the rainy season. The seasonal variation, observed in the transport of these chemical species associated with the FSS of the Sorocaba River, was influenced more by the temporal variability of discharge and FSS concentrations, than by their concentration variations in the dry and rainy seasons, as already reported in the literature for other basins (Kucuksezgin et al., 2008; Radakovich et al., 2008; Song et al., 2010; Wen et al., 2013).

\section{Conclusions}

This study confirms that an integrated approach involving the trace elements and isotopic composition of POM present in the FSS enables a better understanding and identification of how the anthropogenic influences can affect the natural processes acting on a disturbed tropical watershed. Thus, future studies involving traces elements in FSS should be conducted in conjunction with the isotopic analysis of particulate organic matter, preventing mistaken conclusions in identifying the source of these metals in natural or disturbed watersheds. The results showed that the concentrations of $\mathrm{Cu}, \mathrm{Cr}, \mathrm{Zn}, \mathrm{Cd}, \mathrm{Ni}$ and POM were higher in the dry season and subject to a dilution effect during the rainy season, while Sc and Co showed no significant concentration change during the study period. The isotopic and elemental analysis of $\mathrm{C}$ and $\mathrm{N}$ and the $\mathrm{C}: \mathrm{N}$ ratio of particulate organic matter indicated a clear relationship with domestic sewage, a predominant source during the study period. This anthropogenic activity accounted for $99 \%$ of the fluvial POM during the rainy season, and $94 \%$ during the dry season. The evaluation of the origin of trace metals in the FSS through enrichment factors and geoaccumulation index mainly indicated natural sources during both dry and rainy periods. The exception was $\mathrm{Zn}$, which showed a significant anthropogenic contribution in association to POM coming from domestic sewage. The transport of particulate trace elements and POM was higher during the rainy season due to increasing discharge and FSS load, which in this period amounted to $87 \%$ of all FSS flux during the entire study period. In addition, a study of the bioavailability of $\mathrm{Cu}, \mathrm{Cr}, \mathrm{Zn}, \mathrm{Cd}$ and $\mathrm{Ni}$, using sequential selective extraction, and toxicity tests could provide more information about the effects of these micropollutants on FSS and identify their relationship with benthic and epibenthic organisms.

\section{Acknowledgements}

The authors are grateful to FAPESP - Fundação de Amparo à Pesquisa do Estado de São Paulo(Process No. 08/57104-4 and 08/ 09369-9), and to CNPq - Conselho Nacional de Desenvolvimento Científico e Tecnológico, (Process No. 134169/2009-3) for the financial support; to the Stable Isotope Laboratory of the Center for Nuclear Energy in Agriculture (LIE-CENA/USP), São Paulo, Brazil, and to the Environmental Research and Innovation Department of the Luxembourg Institute for Science and Technology (ERIN/LIST), for the research infrastructure. A. M. Fernandes is also grateful to the Graduate Program of the Faculty of Civil Engineering of UNESP Bauru, for the Postdoctoral grant. Specially, Dr. Wen-Xiong Wang (Associate Editor) and two anonymous referees are thanked for their detailed and insightful review comments, which helped to improve the manuscript.

\section{Appendix A. Supplementary data}

Supplementary data related to this article can be found at http:// dx.doi.org/10.1016/j.envpol.2016.08.008.

\section{References}

Alves, R.I.S., Tonani, K.A.A., Nikaido, M., Cardoso, O.O., Trevilato, T.M.B., SeguraMuñoz, S.I., 2010. Avaliação das concentrações de metais pesados em águas superficiais e sedimentos do Córrego Monte Alegre e afluentes, Ribeirão Preto SP. Bras. Rev. Ambiente Água 5 (3), 122-132.

APHA, American Public Health Association, 1999. Standard Methods for the Examination of Water and Wastewater, 20 ed. APHA, Washington D.C.

Amorim, M.A., Moreira-Turcq, P.F., Turcq, B.J., Cordeiro, R.C., 2009. Origem e dinâmica da deposição dos sedimentos superficiais na Várzea do Lago Grande de Curuai, Pará, Brasil. Acta Amaz 39 (1), 165-172. http://dx.doi.org/10.1590/ S0044-59672009000100016.

Barrie, A., Prosser, S.J., 1996. Automated analysis of light-element stable isotope by isotope ratio mass spectrometry. In: Boutton, T.W., Yamasaki, S. (Eds.), Mass Spectrometry of Soils. Academic Press, New York, pp. 1-46.

Barros, G.V., Martinelli, L.A., Novais, T.M.O., Ometto, J.P.H.B., Zuppi, G.M., 2010 Stable isotopes of bulk organic matter to trace carbon and nitrogen dynamics in a estuarine ecosystem in Babitonga Bay (Santa Catarina, Brazil). Sci. Tot. Environ. 408, 2226-2232. http://dx.doi.org/10.1016/j.scitotenv.2010.01.060.

Berto, D., Rampazzo, F., Noventa, S., Cacciatore, F., Gabellini, M., Aubry, F.B. Girolimett, A., Brusà, R.B., 2013. Stable carbon and nitrogen isotope ratios as tools to evaluate the nature of particulate organic matter in the Venice lagoon. Estuar. Coast. Shelf Sci. 135, 66-76. http://dx.doi.org/10.1016/j.ecss.2013.06.021.

Bortoletto Junior, M.J., 2004. Características hidrogeoquímicas e processos erosivos mecânicos e químicos nas bacias de drenagem dos rios Tietê e Piracicaba. Doctoral Thesis. Universidade de São Paulo, São Paulo, Brazil.

BRASIL, 2004. CONAMA (Conselho Nacional do Meio Ambiente), Lei n. 344 de 25 de março de 2004. Diário Oficial da União, Brasília, DF, pp. 56-57 n. 87, 7 de maio de 2004. Seção 1.

Calder, J.A., Parker, P.L., 1968. Stable carbon isotope ratios as indices of petrochemical pollution of aquatic systems. Environ. Sci. Technol. 2, 535-539. http:// dx.doi.org/10.1021/es60019a001.

CCME, Canadian Council of Ministers of the Environment, 1995. Protocol for the derivation of Canadian Sediment Quality Guidelines for the Protection of Aquatic Life. CCME, Ottawa.

Carreira, R.S., Wagener, A.L.R., Readman, J.W., Fileman, T.W., Macko, S.A., Veiga, A., 2002. Changes in the sedimentary organic carbon pool of a fertilized tropical estuary, Guanabara Bay, Brazil: an elemental, isotopic and molecular marker approach. Mar. Chem. 79, 207-227. http://dx.doi.org/10.1016/S0304-4203(02) 00065-8.

Carvalho, C.E.V., Ovalle, A.R.C., Rezende, C.E., Molisani, M.M., Salomão, M.S.M.B., Lacerda, L.D., 1999. Seasonal variations of particulate heavy metals in the Lower Paraíba do Sul River, R.J., Brazil. Environ. Geol. 37 (4), 297-302. http:// dx.doi.org/10.1007/s002540050387.

Cotta, J.A.O., Rezende, M.O.O., Piovani, M.R., 2006. Avaliação do teor de metais em sedimento do rio Betari no Parque Estadual Turístico do Alto Ribeira - PETAR, São Paulo. Bras. Quim. Nova 29 (1), 40-45. http://dx.doi.org/10.1590/S010040422006000100009.

DAEE, Departamento de Águas e Energia Elétrica, 2010. Banco de dados hidrológicos; 2010. Disponivel em: http://www.hidrologia.daee.sp.gov.br/. Acesso em 03 set 2010.

EMBRAPA, Empresa Brasileira de Pesquisa Agropecuária, 2013. Sistema brasileiro de classificação de solos, 3.ed. EMBRAPA, Brasília.

Ferrand, J.L., Hamelin, B., Monaco, A., 1999. Isotopic tracing of anthropogenic $\mathrm{Pb}$ inventories and sedimentary fluxes in the Gulf of Lion (NW Mediterranean Sea). 
Cont. Shelf Res. 19, 23-47. http://dx.doi.org/10.1016/S0278-4343(98)00070-3. Fernandes, A.M. 2012. Características hidrogeoquímicas da bacia de drenagem do rio Sorocaba, SP: processos erosivos mecânicos e químicos. Doctoral Thesis. Universidade de São Paulo, São Paulo, Brazil.

Fernandes, A.M., Nolasco, M.B., Hissler, C., Mortatti, J., 2012. Mechanical erosion in a tropical river basin in Southeastern Brazil: chemical characteristics and annual fluvial transport mechanisms. J. Geol. Res. 8. http://dx.doi.org/10.1155/2012 127109. Article ID 127109.

Finlay, J.C., Kendall, C., 2007. Stable isotope tracing of temporal and spatial variability in organic matter sources to freshwater ecosystems. In: Michener, R Lajha, K. (Eds.), Stable Isotopes in Ecology and Environmental Science, second ed. Blackwell Publications, USA, pp. 283-333. http://dx.doi.org/10.1002/ 9780470691854 ch 10

Gaillardet, J., Viers, J., Dupré, B., 2003. Trace elements in river waters. In: Drever, J.I (Ed.), Treatise on Geochemistry. In: Holland, H.D., Turekian, K.K. (Eds.), Surface and Groundwater, Weathering, Erosion and Soils, Vol. 5. Pergamon, pp. 225-272.

Gao, X., Yang, Y., Wang, C., 2012. Geochemistry of organic carbon and nitrogen in surface sediments of coastal Bohai Bay inferred from their ratios and stable isotopic signatures. Mar. Pollut. Bull. 64, 1148-1155. http://dx.doi.org/10.1016 j.marpolbul.2012.03.028.

Harikumar, P.S., Jisha, T.S., 2010. Distribution pattern of trace metal pollutants in the sediments of as urban wetland in the southwest coast of India. Internat. J. Eng. Sci. Technol. 2 (2), 840-850.

Hissler, C., Hostache, R., Iffly, J.F., Pfister, L., Stille, P., 2015a. Anthropogenic rare earth element fluxes into floodplains: coupling between geochemical monitoring and hydrodinamic sediment transport modeling. C. R. Geosci. 347, 294-303. http:/ dx.doi.org/10.1016/j.crte.2015.01.003.

Hissler, C., Stille, P., Juilleret, J., Iffly, J.F., Perrone, T., Morvan, G., 2015b. Elucidating the formation of terra fuscas using $\mathrm{Sr}-\mathrm{Nd}-\mathrm{Pb}$ isotopes and rare earth elements. Appl. Geochem 54, 85-99. http://dx.doi.org/10.1016/j.apgochem.2015.01.011.

Hissler, C., Probst, J.L., 2006a. Impact of mercury atmospheric deposition on soils and streams in a mountainous catchment (Vosges, France) polluted by chloralkali industrial activity: the important trapping role of the organic matter. Sci. Tot. Environ. 361 (1-3), 163-178. http://dx.doi.org/10.1016/ j.scitotenv.2005.05.023.

Hissler, C., Probst, J.L., 2006b. Chlor-alkali industrial contamination and riverine transport of mercury: distribution and partitioning of mercury between water suspended matter, and bottom sediment of the Thur River, France. Appl. Geochem 21, 1837-1854. http://dx.doi.org/10.1016/j.apgeochem.2006.08.002.

Horowitz, A.J. 2008. Determining annual suspended sediment and sedimentassociated trace element and nutrient fluxes. Sci. Tot. Environ. 400, 315-343. http://dx.doi.org/10.1016/j.scitotenv.2008.04.022.

IBGE, Instituto Brasileiro de Geografia e Estatística, 2010. Dados do Censo 2010 publicados no Diário Oficial da União do dia 04/11/2010. Disponivel em: http:/ www.ibge.gov.br/censo2010/dados_divulgados/index.php/uf=35. Acesso em 03 dez 2010.

IPT, Instituto de Pesquisas Tecnológicas, 2006. Relatório Zero da Bacia do Sorocaba e Médio Tietê - Atualização 2005. IPT, São Paulo, pp. 401-405. Relatório Técnico $n^{\circ} 80$.

Kendall, C., Doctor, D.H., 2003. Stable isotope applications in hydrologic studies. In: Drever, J.I. (Ed.), Treatise on Geochemistry. In: Holland, H.D., Turekian, K.K. (Eds.), Surface and Groundwater, Weathering, Erosion and Soils, Vol. 5. Pergamon, pp. 320-364

Kendall, C., Silva, S.R., Kelly, V.J., 2001. Carbon and nitrogen isotopic composition of particulate organic matter in four large river systems across the United States. Hydrol. Process 15, 1301-1346. http://dx.doi.org/10.1002/hyp.216.

Kersten, M., Forstner, U., 1995. Speciation of trace metals in sediments and combustion waste. In: Ure, A.M., Davidson, C.M. (Eds.), Chemical Speciation in the Environment. Blackie Academic and Professional, London, pp. 234-275.

Krusche, A.V., Martinelli, L.A., Victoria, R.L., Bernardes, M., Camargo, P.B., Ballester, M.V., Trumbore, S.E., 2002. Composition of particulate and dissolved organic matter in a disturbed watershed of southeast Brazil (Piracicaba River basin). Water Res. 36, 2743-2752. http://dx.doi.org/10.1016/S0043-1354(01 00495-X.

Kucuksezgin, F., Uluturhan, E., Batki, H., 2008. Distribution of heavy metals in water, particulate matter and sediments of Gediz River (Eastern Aegean). Environ. Monit. Assess. 141, 213-225. PMID: 17846908.

Leleyter, L., Probst, J.L., 1999. A new sequential extraction procedure for the speciation of particulate trace elements in river sediments. Intern. J. Environ. Anal. Chem. 73 (2), 109-128. http://dx.doi.org/10.1080/03067319908032656.

Martin, J.M., Meybeck, M., 1979. Elemental mass-balance of material carried by major world rivers. Mar. Chem. 7, 173-206. http://dx.doi.org/10.1016/0304 4203(79)90039-2.

Mayer, B., Boyer, E.W., Goodale, C., Jaworski, N.A., Van Breemen, N., Howart, R.W., Seitzinger, S., Billen, G., Lajtha, K., Nadelhoffer, K., Vam Dam, D., Hetling, L.J. Nosal, M., Paustian, K., 2002. Sources of nitrate in rivers draining sixteen watersheds in the northeastern U.S.: isotopic constraints. Biogeochemistry 57/58, 171-197. http://dx.doi.org/10.1023/A:1015744002496.

Meybeck, M., 1993. Riverine transport of atmospheric carbon: sources, global typology and budget. Water Air Soil Pollut. 70, 443-463. http://dx.doi.org 10.1007/BF01105015.

Meybeck, M., Laroche, L., Dürr, H.H., Syvitski, J.P.M., 2003. Global variability of daily total suspended solids and their fluxes in rivers. Glob. Planet. Change 39 65-93. http://dx.doi.org/10.1016/S0921-8181(03)00018-3.
Meybeck, M., Lestel, L., Bonté, P., Moilleron, R., Colin, J.L., Rousselot, O., Hervé, D., de Pontevès, C., Thévenot, D.R., 2007. Historical perspective of heavy metals contamination $(\mathrm{Cd}, \mathrm{Cr}, \mathrm{Cu}, \mathrm{Hg}, \mathrm{Pb}, \mathrm{Zn})$ in the Seine River basin (France) following a DPSIR approach (1950-2005). Sci. Tot. Environ. 375 (1-3), 204-231. http://dx.doi.org/10.1016/j.scitotenv.2006.12.017.

Miller, C.V. Gutiérrez-Magness, A.L., FeitMajedi, B.L, Foster, G.D. 2007. Water Quality in the Upper Anacostia River, Maryland: Continuous and discrete Monitoring with Simulations to Estimate Concentrations and Yields, 2003-05. U.S. Geological Survey Investigations Report 2007-5142, p. 43.

Moreira-Turq, P., Bonett, M.P., Amorim, M., Bernardes, M., Lagane, C., Maurice, L., Perez, M., Seyler, P., 2013. Seasonal variability in concentration, composition, age, and fluxes of particulate organic carbon exchanged between the floodplain and Amazon River. Glob. Biogeochem. Cycle 27 (1), 119-130. http://dx.doi.org/ $10.1002 / g b c .20022$.

Mortatti, J., 1995. Erosão na Amazônia: processos, modelos e balanços. Thesis Livre Docência. Universidade de São Paulo, São Paulo, Brazil.

Mortatti, J., Moraes, G.M., Probst, J.L., 2012. Heavy metals distribution in recent sediments along the Tietê River basin (São Paulo, Brazil). Geochem. J. 46, 13-19. http://dx.doi.org/10.2343/geochemj.1.0136.

Mortatti, J., Probst, J.L., 2010. Characteristics of heavy metals and their evaluation in suspended sediments from Piracicaba river basin (São Paulo, Brazil). Rev. Bras. Geocienc. 40 (3), 375-379.

Mortatti, J., Probst, J.L., 1998. Hidrogeoquímica de bacias de drenagem. CPG/CENA, Piracicaba.

Mozeto, A.A., Silvério, P.F., DePaula, F.C.F., Bevilacqua, J.E., Patella, E., Jardim, W.R., 2003. Weakly-bound metals and total nutrient concentrations of bulk sediments from some reservoirs in São Paulo State, SE, Brazil. In: Munawar, M. (Ed.), Sediment Quality Assessment and Management: Insight and Progress. Backhuys Publishing, Leiden, NE, pp. 221-239.

Mukherjee, D.P., 2014. Dynamics of metal ions in suspended sediments in Hugli estuary, India and its importance towards sustainable monitoring program. J. Hydrol. 517, 762-776. http://dx.doi.org/10.1016/j.hydrol.2014.05.069.

Müller, G., 1979. Schwermetalle in the Sedimentendêsrheins-veränderungenseit. Umschau, Frankfurt 79, pp. 133-149.

Nasrabadi, T., Bidhendi, G.N., Karbassi, A., Mehrdadi, N., 2010. Evaluating the efficiency of sediment metal pollution indices in interpreting the pollution of Haraz River sediments, southern Caspian Sea basin. Environ. Monit. Assess. 171, 395-410. http://dx.doi.org/10.1007/s10661-009-1286-x.

N'guessan, Y.M., Probst, J.L., Bur, T., Probst, A., 2009. Trace elements in stream bed sediments from agricultural catchments (Gascogne region, S-W France): where do they come from? Sci. Tot. Environ. 407, 2939-2952. http://dx.doi.org/ 10.1016/scitotenv.2008.12.047.

Nriagu, J.O., 1988. A silent epidemic of environmental metal poisoning? Environ. Pollut. 50, 39-61. http://dx.doi.org/10.1016/0269-7491(88)90189-3.

Oliveira, J.B., Camargo, M.N., Rossi, M., Calderano Filho, B., 1999. Mapa pedológico do Estado de São Paulo: legenda expandida. Instituto Agronômico, Campinas. Embrapa-Solos, Rio de Janeiro, p. 64 (mapa).

Ollivier, P., Radakovich, O., Hamelin, B., 2011. Major and trace element partition and fluxes in the Rhône River. Chem. Geol. 285, 15-31. http://dx.doi.org/10.1016/ j.chemgeo.2011.02.011.

Probst, J.L., Amiotte-Suchet, P., Tardy, Y., 1992. Global continental erosion and fluctuations of atmospheric $\mathrm{CO}_{2}$ consumed during the last 100 years. WaterRock Interact. 483-486.

Radakovich, O., Roussiez, V., Ollivier, P., Ludwig, W., Grenz, C., Probst, J.L., 2008. Input of particulate heavy metals from rivers and associated sedimentary deposits on the Gulf of Lion continental shelf. Estuar. Coast. Shelf Sci. 77, 285-295. http://dx.doi.org/10.1016/j.ecss.2007.09.028.

Rodrigues, A.S., Nalini Junior, H.A., 2009. Valores de fundo geoquímico e suas implicacões em estudos ambientais. Rev. Esc. Minas 62, 155-165.

Ross, J.L.S., 1996. Geografia do Brasil. EDUSP, São Paulo.

Ross, J.L.S., Moroz, I.C., 1997. Mapa geomorfológico do Estado de São Paulo. Laboratório de Geomorfologia/Departamento de Geografia/FFLCH-USP (Laboratório de Cartografia Geotécnica - Geologia Aplicada - IPT, FAPESP. Mapas e relatórios - SP, São Paulo)

Roussiez, V., Probst, A., Probst, J.L., 2013. Significance of floods in metal dynamics and export in a small agricultural catchment. J. Hydrol. 499, 71-81. http:// dx.doi.org/10.1016/j.jhydrol.2013.06.013.

Salomons, W., Forstner, U., 1984. Metals in the Hidrocycle. Springer-Verlag, Berlim.

Samuel, J., Rouault, R. Besnus, Y., 1985. Analyse multiémentaire standardisée des materiaux géologiques en spectrométried'émission par plasma a couplage inductif. Analusis 13 (7), 312-317.

Santos, G.A., Camargo, F.A.O., 1999. Fundamentos da matéria orgânica do solo: ecossistemas tropicais e subtropicais. Gênesis, Porto Alegre.

Sardinha, D.S., Bonotto, D.M., Conceição, F.T., 2010. Weathering rates at Alto Sorocaba basin, Brazil, using U-isotopes and major cations. Environ. Earth Sci. 61, 1025-1036. http://dx.doi.org/10.107/s12665-009-0424-7.

Sarma, V.V.S.S., Arya, J., Subbaiah, C.V., Naidu, S.A., Gawade, L., Praveen Kumar, P., Reddy, N.P.C., 2012. Stable isotopes of carbon and nitrogen in suspended matter and sediments from the Godavari estuary. J. Oceanogr. 68, 307-319. http:// dx.doi.org/10.1007/s10872-012-0100-5.

Shotyk, W., Blaser, P., Grüning, A., Cheburkin, A.K., 2000. A new approach for quantifying cumulative, anthropogenic, atmospheric lead deposition using peat cores from bogs: $\mathrm{Pb}$ in eight Swiss peat bog profiles. Sci. Tot. Environ. 249, 281-295. http://dx.doi.org/10.1016/S0048-9697(99)00523-9.

Song, Y., Ji, J., Mao, C., Yang, Z., Yuan, X., Ayoko, G.A., Frost, R.L., 2010. Heavy metal 
contamination in suspended solids of Chiangjiang River - environmental implications Geoderma j.geoderma.2010.07.020.

Tamooh, F., Van den Meersche, K., Meysman, F., Marwick, T.R., Borges, A.V., Merckx, R., Dehairs, F., Schmidt, S., Nyunja, J., Bouillon, S., 2012. Distribution and origin of suspended matter and organic carbon pools in the Tana River Basin, Kenya. Biogeosciences 9, 2905-2920. http://dx.doi.org/10.5194/bg-9-29052012.

Taylor, S.R., McLennan, S.M., 1995. The geochemical evolution of the continental crust. Rev. Geophys. 33 (2), 241-265. http://dx.doi.org/10.1029/95RG00262.

Tessier, A., Campbell, P.G.C., Bisson, M., 1979. Sequential extraction procedure for the speciation of particulate trace metals. Anal. Chem. 51 (7), 844-851. http:// dx.doi.org/10.1021/ac50043a017.

Tessier, A., Campbell, P.G.C., 1987. Partitioning of trace metals in sediments: relationship with bioavailability. Hydrobiologia 149 (1), 43-52. http://dx.doi.org/ 10.1007/BF00048645.

USDA, United States Department of Agriculture, 1999. Soil Taxonomy - a Basic System of Soil Classification for Making and Interpreting Soils Surveys, 2 ed. US Government Office, Washington DC.

Viers, J., Dupré, B., Gaillardet, J., 2009. Chemical composition of suspended sediments in World Rivers: new insights from a new database. Sci. Tot. Environ. 407, 853-868. http://dx.doi.org/10.1016/j.scitotenv.2008.09.053.

Walling, D.E., 2013. The evolution of sediment source fingerprinting investigations in fluvial systems. J. Soils Sediments 13, 1658-1675. http://dx.doi.org/10.1007/ s11368-013-0767-2.

Walling, D.E., 2005. Tracing suspended sediment sources in catchments and river systems. Sci. Tot. Environ. 344, 159-184. http://dx.doi.org/10.1016| j.scitotenv.2005.02.011.

Wen, Y., Yang, Z., Xia, X., 2013. Dissolved and particulate zinc and nickel in the Yangtze River (China); distribution, sources and fluxes. Appl. Geochem 31, 199-208. http://dx.doi.org/10.1016/j.apgeochem.2013.01.004.

Woitke, P., Wellmitz, J., Helm, D., Kube, P., Lepom, P., Litheraty, P., 2003. Analysis and assessment of heavy metal pollution in suspended solids and sediments of the river Danube. Chemosphere 51, 633-642. http://dx.doi.org/10.1016/S00456535(03)00217-0.

Zhang, J., Liu, C.L., 2002. Riverine composition and estuarine geochemistry of particulate metals in China - weathering features, anthropogenic impact and chemical fluxes. Estuar. Coast. Shelf Sci. 54, 1051-1070. http://dx.doi.org/ 10.1006/ecss.2001.0879. 